\title{
31. 国土数值情報土地利用細分メッシュデータを用いた人口動態と土地利用変化の関係性
}

- メッシュ人口密度・メッシュ人口変化率に着目して -

Relationship between population change and land use change used by land use subdivision mesh data

- Focusing on population density and rate of population change -

高柳 誠也*

Seiya Takayanagi*

The number of population has been decreasing in Japan. It is not so clear how to change land use in population decreasing situation in Japan. It is needed to be clear the tendency of land use change in population decreasing area for national land planning. In this paper, database of population change and land use change is made from population mesh data and land use subdivision mesh data. Focusing on population density and rate of population change, it is pointed out that the tendency of land-use change or remain is different for every type of land use.

Keywords: Land use change, Population change, Land use subdivision mesh data, Non-residential area 土地利用変化，人口動態，土地利用細分メッシュデータ，無住化地域

\section{1. 研究の背景と目的 \\ 1-1 研究の背景·目的}

日本は人口減少社会に突入し，人口減少に対応した土地 利用政策が必要とされている．それに伴い，人口構造と土 地利用との関係について把握することの重要性が高まって いる．「国土のグランドデザイン 2050」では，人口減少に 対応した国土計画として地域の多様性を重視することが述 べられている ${ }^{11}$ ．今後，都市・農村計画分野においても人 口減少に対応した計画·取組が行われることが予想される.

人口減少社会に対しては多くの提言が行われているが, 実際に人口と土地利用との関係性について言及したものは 少ない，また，都市計画分野において特定の地域を対象と した解析は行われているが，国土全体を対象としたものは 少ない，今後人口が減少する中で，全国において人口動態 に応じた土地利用変化や，無住化した地域の土地利用変化 について過去のデータから把握することは重要である.

以上のような背景から, 本研究は, 1995 年および 2010 年 における国勢調査の人口統計と 1991 年度および 2009 年度 における国土数值情報の土地利用細分メッシュデータを結 合し，国土全体を対象とした人口動態と国土数值情報デー 夕に基づく土地利用との関係性について整理し，その傾向 について分析する. 人口減少の状況や地域の環境（都市部 や農村部など）を考慮し，特に，人口密度や人口変化率に 着目し，土地利用変化の傾向を土地利用種別ごとに整理・ 分析すること，無住化した地域における土地利用変化につ いても把握することを目的とする. 人口変化率に着目した のは，人口変化率 (減少率) が大きい場合，その地域の環 境が変化している可能性が高いことが想定され，土地利用 変化にも変化率に応じて異なる傾向生じると予想されるか らである.また，人口密度に着目したのは都市部と農村部
など地域の環境に忘じて土地利用変化の傾向も異なると予 想されるからである．更に，人口減少が著しく無住化した 地域については特に土地利用種別ごとに土地利用変化につ いて把握することで，今後の人口減少社会によって多数生 じる可能性が高い無住化地域に対する対応策を講じるため の基礎的知見となると考えた.

本研究では土地利用変化の要因についての考察は行わな いが，今後の人口減少社会における土地利用（国土利用） 変化について検討寸るための基礎資料，人口動態と土地利 用変化の要因をより精緻に把握するための基礎的資料とな ることが想定される.

\section{1-2 既往研究と本研究の位置づけ}

国勢調査人口メッシュデータを用いた研究としては，有 賀ら(2011)による，自然増減と社会増減を考慮した人口分 布変化の研究 2)や, 中西ら(2011)による都市構造の可視化に 関する研究 3などがあるが，いずれも特定の地域における 分析を行った研究である. また，人口動態と土地利用に関 する研究としては，清水ら（1999）による土地利用構造の 把握に関寸る研究 4$)$ や, 㐘池ら(2015)による都市地域におけ る人口減少と土地利用変化に関寸る研究 5), 清水(2015)によ る標準地域 3 次メッシュを用いた土地利用変化と人口・世 帯数変化に関する研究 6)がある. 清水ら(1999)の研究 5)は全 国の土地利用変化を対象としているものの，市区町村単位 での分析である. 菊池ら(2015)の研究 )は, 土地利用 3 次メ ッシュを用いた上で都市地域のみを分析対象としている. 清水(2015)の研究 6)は土地利用 3 次メッシュを用いて全国 を対象とした上で, 2005-2010 年における人口・世帯数に着 目した上で都市的土地利用の変化について整理し，都市地 域における自然的土地利用と都市的土地利用がモザイク化 することを指摘している.

*学生会員 東京大学大学院工学系研究科 (The University of Tokyo, School of Engineering) 
本研究は，全国を対象として土地利用 3 次メッシュ（約 $1 \mathrm{~km}$ ）データよりも更に解像度の高い土地利用細分メッシ ユ（約 $100 \mathrm{~m}$ ) データを用い，都市地域のみならず全国を 対象として都市的土地利用以外の分類（特に田および農用 地）について分析を行った点，国勢調査の人口メッシュデ 一タを重㸚わせた上で，そのメッシュ人口密度及び人口 変化率に着目し，それぞれに対して土地利用変化について の特徵を把握している点，また，無住化する地域における 土地利用変化の特徵について把握している点に新規性があ る，また，その結果として，人口減少社会における土地利 用変化についての傾向を指摘している点に独自性がある.

\section{2. 研究方法}

\section{2-1 使用データ}

本研究において，土地利用メッシュデータは，国土数值 情報土地利用細分メッシュデータを用いた．国土数值情報 における土地利用関連のメッシュデータは，土地利用 3 次 メッシュ (約 $1 \mathrm{~km}$ 四方)，土地利用細分メッシュ (約 $100 \mathrm{~m}$ 四方)，都市地域土地利用細分メッシュ（約 $10 \mathrm{~m}$ 四方）が 整備されている，土地利用 3 次メッシュにおいては，都市 部以外の集落などの居住地について判別が難しい解像度で あり，既に人口減少が進行している地域のより詳細な土地 利用の詳細を把握するのが困難である．また，都市地域土 地利用細分メッシュは，都市地域以外のデータが整備され ていないことから，国土全体を把握できない，以上のこと から，土地利用細分メッシュデータを利用した。

人口メッシュデータは, 国勢調査人口メッシュデータ(世 界測地系 $1 \mathrm{~km}$ メッシュ）を利用した. 国勢調査人口メッシ ユデータは 250m ないし 500m メッシュも存在するが，土 地利用細分メッシュとのデータ結合に際して調整事項が多 いことや，国勢調査の時期によって提供されていないもの もあったために，1kmメッシュを用いた.

人口データの推移と土地利用データの変化の時期のずれ が少なくなるように，国勢調査人ロメッシュデータについ ては, $1 \mathrm{~km}$ メッシュデータが提供されている最も古い 1995

表-1 総メッシュ・対象メッシュ数

\begin{tabular}{|c|c|c|}
\hline \multirow{2}{*}{ 総メッシュ数 } & \multicolumn{2}{|c|}{ 1995年国勢調査メッシュ人口 } \\
\cline { 2 - 3 } & 1名以上(居住地) & 0名（非居住地） \\
\hline \multirow{2}{*}{$34,132,665$} & $13,515,730(39.6 \%)$ & $20,616,935(60.40 \%)$ \\
\hline
\end{tabular}

表-2 土地利用類型

\begin{tabular}{|c|c|c|}
\hline 1991年土地利用 & 2009年土地利用 & 本研究での土地利用類型 \\
\hline 田 & 田 & 田 \\
\hline その他農用地 & その他農用地 & 農用地 \\
\hline 森林 & 森林 & \multirow{2}{*}{ 森林 - 荒地 } \\
\hline 荒地 & 荒地 & \\
\hline 建物用地 & 建物用地 & 建物 \\
\hline \multirow{2}{*}{ 幹線交通用地 } & 道路 & \multirow{3}{*}{ 交通. その他 } \\
\hline & 鉄道 & \\
\hline その他の用地 & その他の用地 & \\
\hline 河川地及び湖沼 & 河川地及び湖沼 & \multirow{3}{*}{ 水域 } \\
\hline 海浜 & 海浜 & \\
\hline 海水域 & 海水域 & \\
\hline ゴルフ場 & ゴルフ場 & ゴルフ場 \\
\hline
\end{tabular}

年および最新の 2010 年のデータ，土地利用細分メッシュ データは 1991 年度および 2009 年度のデータを用いた(1).

\section{2-2 データベースの構築·対象メッシュ}

本研究では土地利用および人口についてメッシュデータ を結合したデータベースを GIS 上で構築した.メッシュ結 合にあたっては, 土地利用細分メッシュ(約 100m)を基準と し，国勢調査人ロメッシュ (約 $1 \mathrm{~km})$ については，メッシ ユコードと一致するすべてのメッシュに情報を付与した(2)

全国におけるメッシュ数は, 3,400 万余りとなったが, 本 研究においては, 1995 年の段階でメッシュ人口が 1 人以上 であるメッシュ約 1,350 万メッシュを対象として分析を行 った(表-1). また，土地利用細分メッシュデータは年度に応 じて分類が異なるため，表-2のように土地利用類型を整理 した上で分析を行った. 具体的な分析にあたっては, 「建物」 「田」「農用地」メッシュに着目して整理を行った。

\section{3. 人口動態(変化率)之土地利用変化との関係 3-1 1991-2009 年度における土地利用変化}

対象全メッシュの 1991 年度および 2009 年度における土 地利用について整理し，土地利用類型に変化がなかったも ののメッシュ数の割合を残存率とし，土地利用類型別に整 理したものが表-3 である. 記載類型ごとのメッシュ数の変 化に着目すると，「建物」の増加率が最も高く(1.56 倍),「ゴ ルフ場」も微増(1.07倍)している. それに対して「交通・そ の他」 (0.72 倍),「田」(0.85 倍),「水域」(0.89 倍),「農用地」 (0.93 倍)は減少している(3).「森林・荒地」は大きく変化し ていない (0.99倍)。全メッシュの 80.2\%は土地利用類型の 変化がなく，19.8\%に変化があった．変化が少ない「森林・ 荒地」を除く6 類型合計では, $72.2 \%$ に土地利用類型の変化 がなく, 27.8\%に変化があった.

また，1991 年度および 2009 年度における土地利用類型 構成比を比較すると，「建物」メッシュの構成比が $10.6 \%$ か ら 16.6\%と増加し，「田」メッシュの構成比が 20.9\%から 17.7\%と減少している点の変化が大きい。「農用地」「交通・ その他」「水域」メッシュの構成比も微减している.このこ とから，国土全体として都市的地域が増加し，田や農地な どの農業的土地利用が減少していることがわかる.

残存率に着目寸ると，「森林・荒地」「建物」メッシュの 残存率は高く，「交通・その他」の残存率が低い. また，「農 用地」は残存率が 7 割以下であるが，メッシュ総数や構成 比が「田」や「建物」に比べて変化が小さいことから，農 地一の転用と農地からの転用が同程度起こっていることを 観察することができる.

土地利用類型の変化の有無の分布について,「建物」「田」

「農用地」メッシュに着目し，各類型の変化なし (残存) および変化ありの分布図を作成した(図-3,4,5).「建物」メッ シュについては，都市部や市町村の中心部を中心に多くの 残存が見られる.「建物」から変化したメッシュは, 全国に まばらに存在しており，地域的な偏在をみることはできな 
表-3 1991 年度及び 2009 年度における土地利用メッシュ数

\begin{tabular}{|c|c|c|c|c|c|c|c|c|c|c|c|}
\hline & \multicolumn{9}{|c|}{ 2009年度土地利用 } & \multirow{3}{*}{$\begin{array}{r}\text { 残存率 } \\
73.72 \%\end{array}$} \\
\hline & & 田 & 農用地 & 森林・荒地 & 建物 & 交通・その他 & 水域 & ゴルフ場 & 小計（構 & 戈比） & \\
\hline \multirow{9}{*}{$\begin{array}{l}\text { 1991年度 } \\
\text { 土地利用 }\end{array}$} & 田 & $2,086,095$ & 127,482 & 191,444 & 353,348 & 45,087 & 25,220 & 1,056 & $2,829,732$ & $20.94 \%$ & \\
\hline & 農用地 & 74,189 & $1,310,915$ & 222,725 & 222,953 & 40,260 & 12,438 & 2,152 & $1,885,632$ & $13.95 \%$ & $69.52 \%$ \\
\hline & 森林. 荒地 & 111,943 & 228,527 & $5,489,993$ & 152,720 & 82,571 & 31,210 & 15,525 & $6,112,489$ & $45.23 \%$ & $89.82 \%$ \\
\hline & 建物 & 55,229 & 50,454 & 49,108 & $1,234,290$ & 35,180 & 6,809 & 239 & $1,431,309$ & $10.59 \%$ & $86.24 \%$ \\
\hline & 交通. . その他 & 23,431 & 23,473 & 56,511 & 238,345 & 131,623 & 9,552 & 6,445 & 489,380 & 3. $62 \%$ & $26.90 \%$ \\
\hline & 水域 & 43,470 & 16,736 & 48,103 & 35,803 & 14,464 & 536,213 & 1,722 & 696,511 & $5.15 \%$ & $76.99 \%$ \\
\hline & ゴルフ場 & 776 & 920 & 17,496 & 1,106 & 1,183 & 666 & 48,530 & 70,677 & $0.52 \%$ & $68.66 \%$ \\
\hline & \multirow{2}{*}{ 小計（構成比） } & $2,395,133$ & $1,758,507$ & $6,075,380$ & $2,238,565$ & 350,368 & 622,108 & 75,669 & $13,515,730$ & $100.00 \%$ & \\
\hline & & $17.72 \%$ & $13.01 \%$ & $44.95 \%$ & $16.56 \%$ & $2.59 \%$ & $4.60 \%$ & $0.56 \%$ & $100.00 \%$ & 2 & ( \\
\hline
\end{tabular}

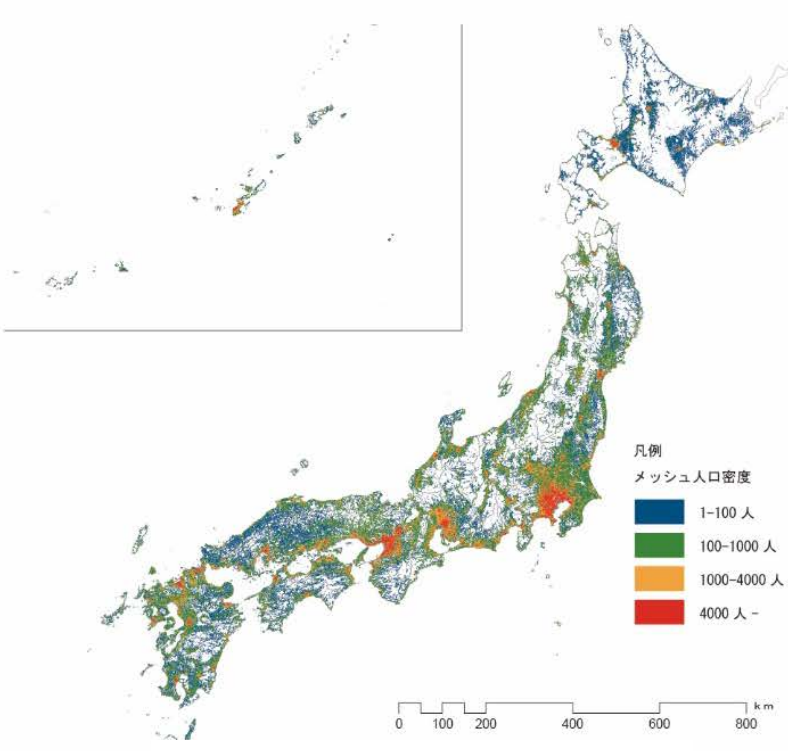

図-1１995年メッシュ人口密度別分布

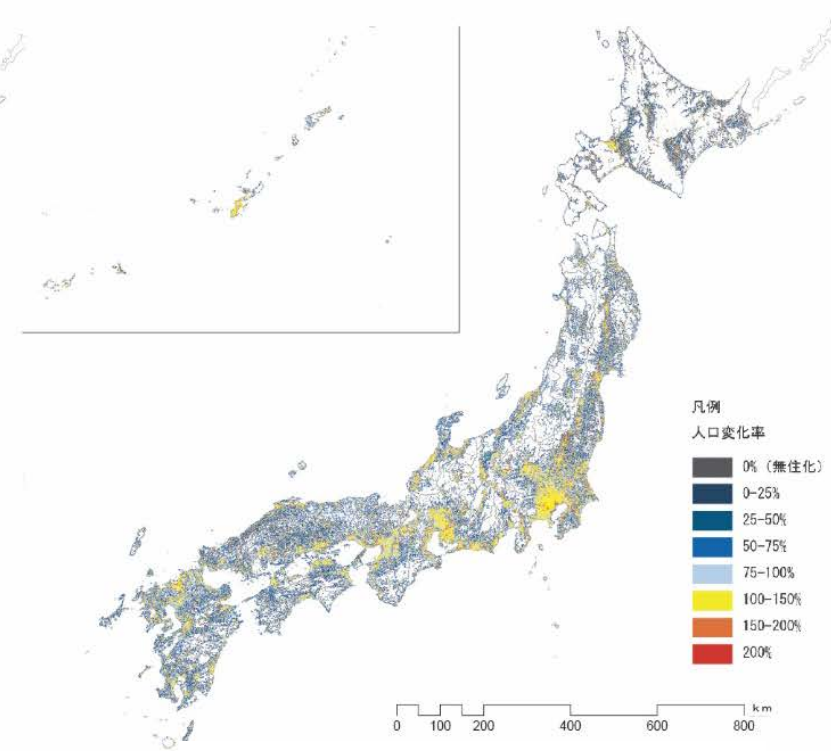

図-2１995年 2010 年メッシュ人口変化率別分布
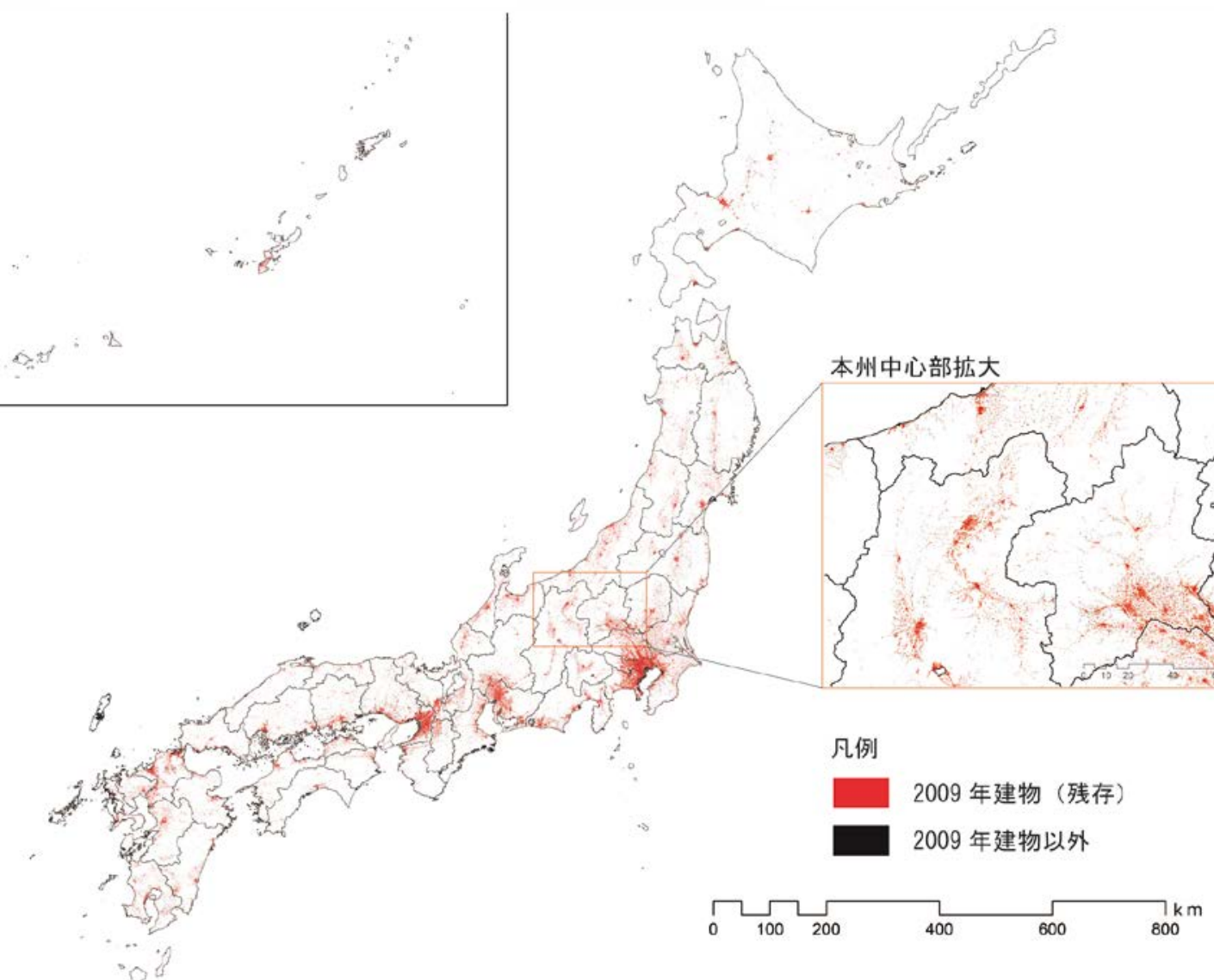

図-3 1991年度「建物」メッシュかつ 2009年度「建物」及び「建物」以外メッシュの分布 


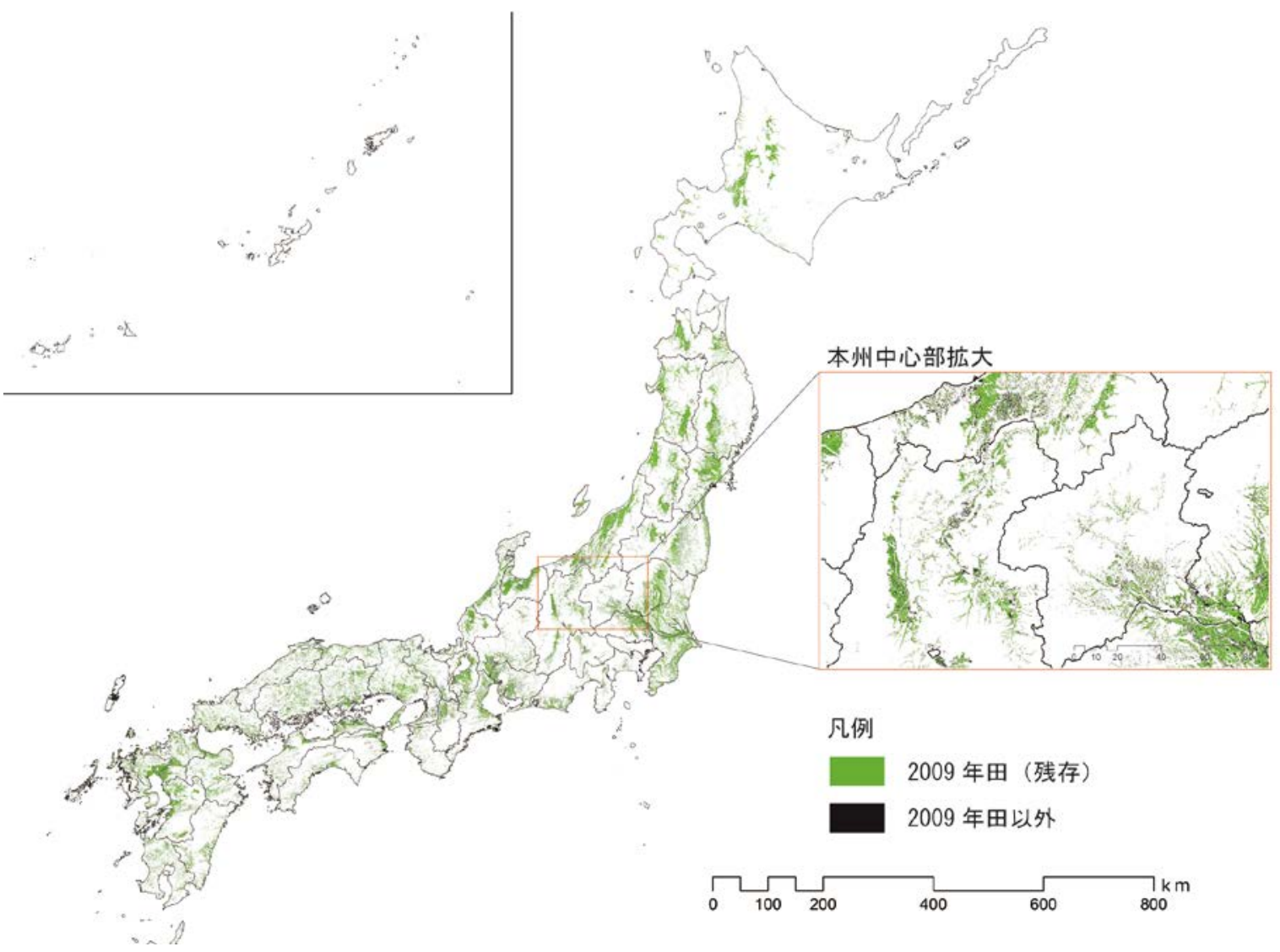

図-4 1991年度「田」メッシュかつ2009 年度「田」及び「田」以外メッシュの分布

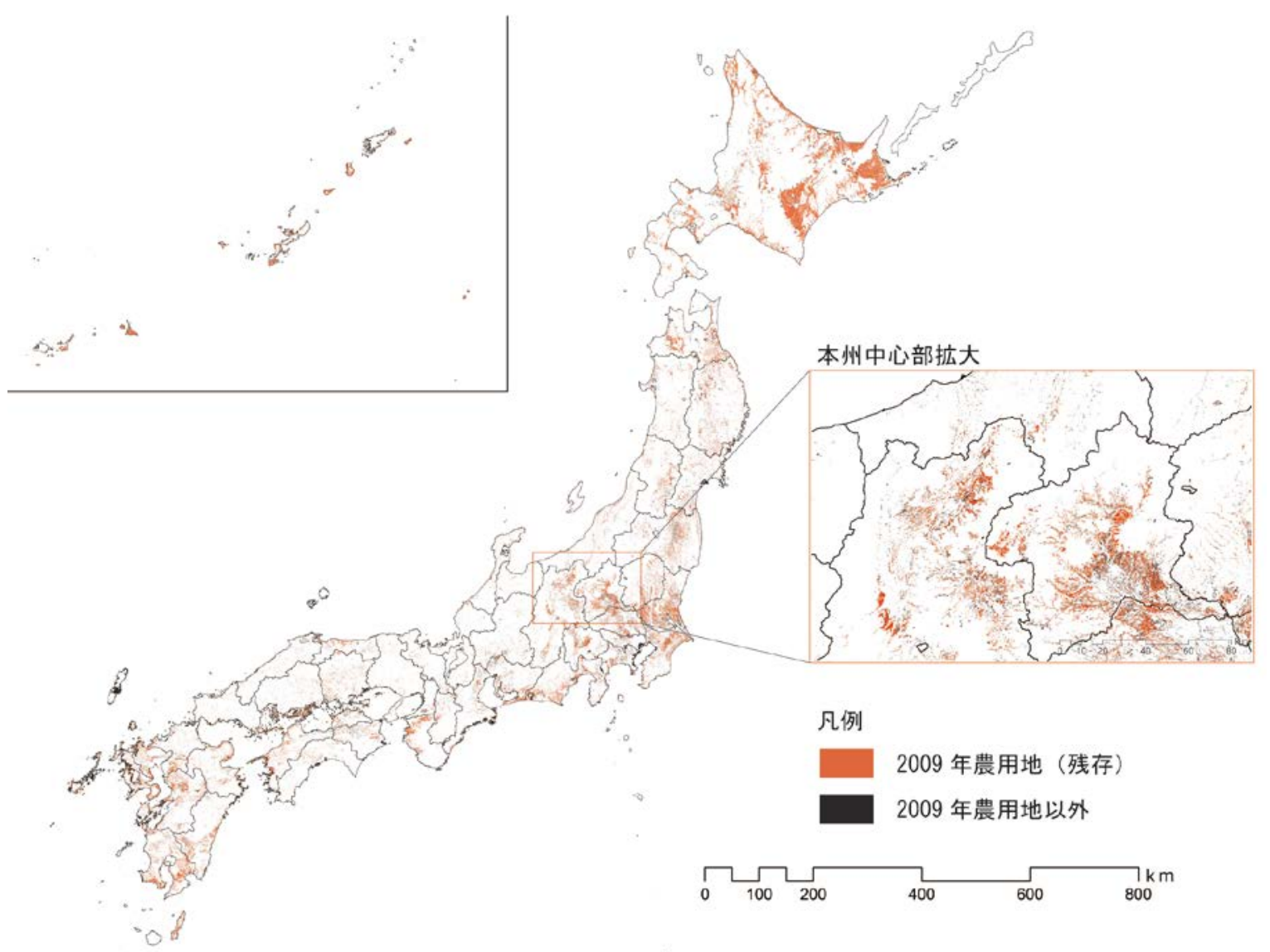

図-5 1991 年度「農用地」メッシュかつ 2009年度「農用地」及び「農用地」以外メッシュの分布 
表-4 メッシュ人口区分別 メッシュ総数

\begin{tabular}{|l|r|r|}
\hline メッシュ人口 & メッシュ数 & \multicolumn{1}{|c|}{ 構成比 } \\
\hline $1-100$ & $5,038,433$ & $37.28 \%$ \\
\hline $100-1000$ & $6,070,630$ & $44.92 \%$ \\
\hline $1000-4000$ & $1,617,635$ & $11.97 \%$ \\
\hline $4000-$ & 789,032 & $5.84 \%$ \\
\hline
\end{tabular}

\begin{tabular}{|c|r|r|r|r|r|}
\hline 1991年度土地利用分類 & \multicolumn{5}{|c|}{ 建物 } \\
\hline 2009 年度土地利用分類 & \multicolumn{1}{|c|}{ 建物 (残存) } & \multicolumn{1}{|c|}{ 森林・荒地 } & \multicolumn{1}{c|}{ 全メッシュ } \\
\hline $1-100$ & 44,606 & 8,356 & 10,966 & 10,679 & 77,785 \\
\hline $100-1000$ & 352,462 & 35,211 & 28,900 & 25,747 & 455,648 \\
\hline $1000-4000$ & 390,479 & 10,325 & 8,554 & 8,803 & 430,547 \\
\hline $4000-$ & 446,743 & 1,337 & 2,034 & 3,879 & 467,329 \\
\hline
\end{tabular}

\begin{tabular}{|c|c|c|c|c|c|}
\hline 1991年度土地利用分類 & \multicolumn{5}{|c|}{ 田 } \\
\hline 2009年度土地利用分類 & 建物 & 田 (残存) & 農用地 & 森林・荒地 & 全メッシュ \\
\hline $1-100$ & 21,155 & 444,548 & 52,660 & 82,390 & 612,834 \\
\hline $100-1000$ & 161,971 & $1,361,991$ & 61,544 & 98,160 & $1,724,369$ \\
\hline $1000-4000$ & 131,411 & 258,676 & 12,100 & 9,823 & 427,714 \\
\hline $44000-$ & 38,811 & 20,880 & 1,178 & 1,071 & 64,815 \\
\hline
\end{tabular}

\begin{tabular}{|c|r|r|r|r|r|}
\hline 1991年度土地利用分類 & \multicolumn{5}{|c|}{ 農用地 } \\
\hline 2009 年度土地利用分類 & \multicolumn{1}{|c|}{ 建物 } & \multicolumn{1}{|l|}{ 田 } & 用地 (残存) & \multicolumn{1}{c|}{ 森林・荒地 } & \multicolumn{1}{c|}{ 全メッシュ } \\
\hline $1-1400$ & 24,018 & 21,928 & 635,452 & 102,674 & 804,359 \\
\hline $100-1000$ & 97,587 & 42,609 & 558,705 & 103,650 & 826,634 \\
\hline $1000-4000$ & 72,523 & 8,980 & 103,051 & 14,462 & 207,649 \\
\hline $4000-$ & 28,825 & 672 & 13,707 & 1,939 & 46,990 \\
\hline
\end{tabular}

い.「田」メッシュの変化したメッシュに着目すると都市 圈に近い部分や，残存しているメッシュの周辺部に分布し ていることが観察できる.これは，都市化による影響や， 生産性の低い山間部などから土地利用が変化しているので はないかと推測される。「農用地」についても「田」と同 様に都市圈周辺における都市化の影響などが観察できる.

以上のように，「建物」「田」「農用地」類型メッシュにお いては, 残存および変化において, 空間的な偏在について 明確に観察することができない．

\section{3-2 メッシュ人口密度と土地利用変化との関係}

1995 年国勢調査人口メッシュデータにおけるメッシュ 人口密度（1 メッシュあたりの人口）の区分別による土地 利用変化の傾向について整理した. 人口密度は 100 人未満, 100 人以上 1000 人未満, 1000 人以上 4000 人未満, 4000 人 以上（DID 地域に相当）の 4 区分に分割した. 各区分に該 当するメッシュ数は表-4 の通りである.

各区分別の土地利用類型構成比について整理したものが 図-6および図-7である. 1-100 人区分においては構成比 に大きな変化は見られないが, 100-1000 人区分, 1000-4000

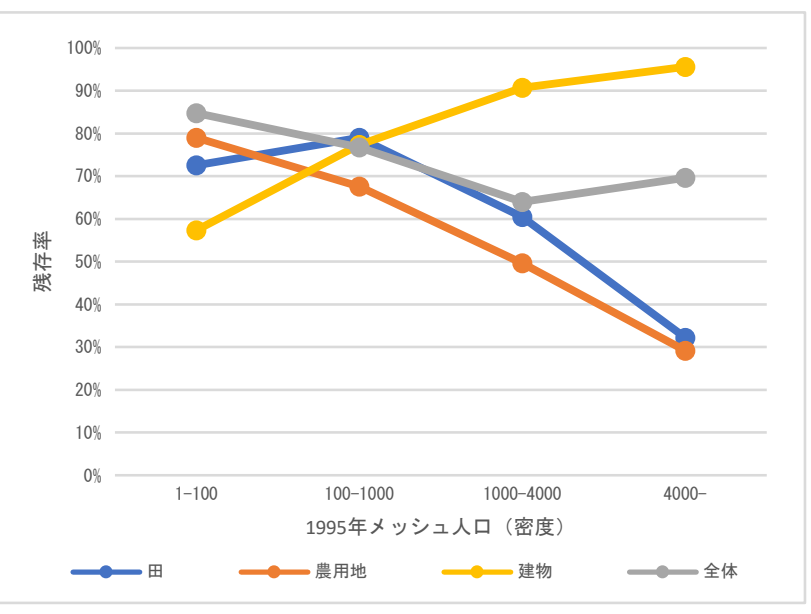

図-8 メッシュ人口密度別 土地利用残存率

人区分，4000 人以上区分においては「建物」メッシュ構成 比が増大し，高密になるにつれ，「田」「農用地」メッシュ 構成比が低減していくことがわかる。

「田」「農用地」「森林・荒地」「建物」における各区分別 の残存率について示したものが図-8 である.「建物」メッシ ユは高密になるにつれ残存率が高く, メッシュ人口 1-100 人の区分においては残存率が約57\%であるが, $1000-4000$ 人 区分においては, 90\%を超え, 4000 人以上の区分では約 $96 \%$ とかなり高い割合となる. それに対して,「農用地」「森林・ 荒地」は高密になるにつれ残存率が低下寸る．特に「農用 地」は1-100 人区分においては約 79\%であるが，1000-4000 人区分においては約 $50 \%$ となり, 4000 人以上の区分におい ては, 約 29\%まで低下寸る.「田」は1-100 人区分における 残存率は約 73\%であるが，100-1000 人区分においては，約 79\%立微増する. また, 1000-4000 人区分においては約 60\%, 4000 人以上区分においては約 $32 \%$ と減少する.

次に，「建物」「田」「農用地」における各メッシュ人口密 度区分別における土地利用変化について整理した(表-5). 「建物」メッシュに着目すると，土地利用変化率は変化す 
表-6 メッシュ人口変化率別 メッシュ総数

\begin{tabular}{|c|r|r|}
\hline $\begin{array}{c}\text { メッシュ人口 } \\
\text { 変化率 (\%) }\end{array}$ & \multicolumn{1}{|c|}{ メッシュ数 } & \multicolumn{1}{c|}{ 構成比 } \\
\hline 0 (無住化) & 569,593 & $4.40 \%$ \\
\hline $0-25$ & 705,347 & $5.45 \%$ \\
\hline $25-50$ & $1,588,552$ & $12.27 \%$ \\
\hline $50-75$ & $2,896,385$ & $22.37 \%$ \\
\hline $75-100$ & $3,696,423$ & $28.55 \%$ \\
\hline $100-150$ & $2,946,500$ & $22.76 \%$ \\
\hline $150-200$ & 589,602 & $4.55 \%$ \\
\hline $200-$ & 523,328 & $4.04 \%$ \\
\hline \multicolumn{2}{|c}{} \\
\hline
\end{tabular}

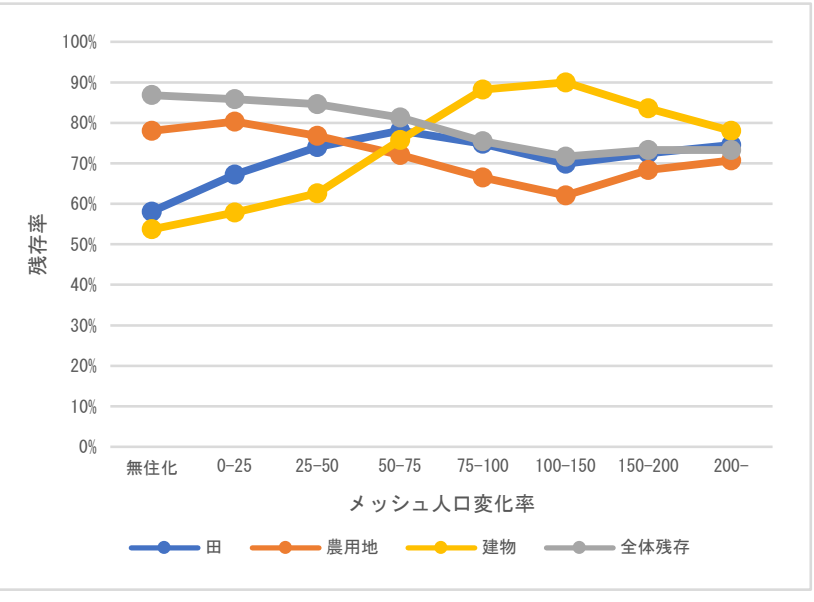

図-11 メッシュ人口変化率别分布

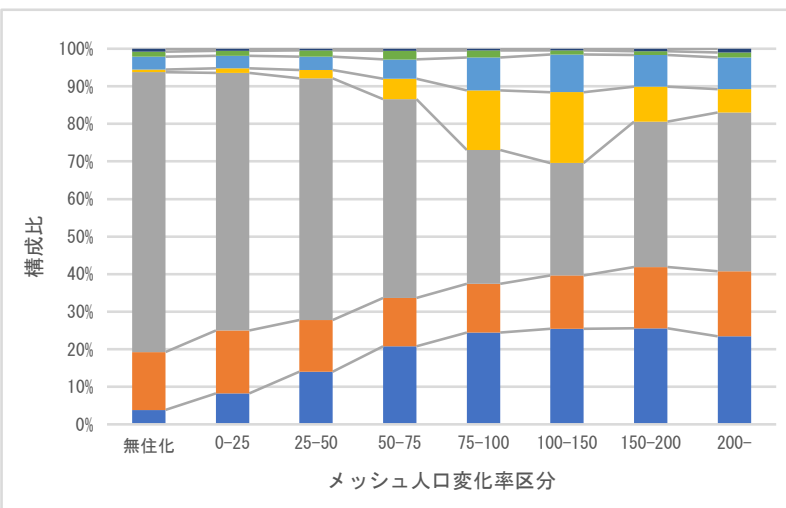

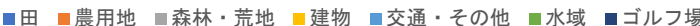

図-9１991 年度メッシュ人口変化率別構成比

るものの，変化した後の土地利用については，「田」「農用 地」「森林・荒地」の割合に大きな差はなく，1-100 人区分 においては 1991 年度「建物」メッシュの内約 11 14\%, 1001000 人区分においては約 6 8\%の割合となっている.「田」 メッシュに着目寸ると, 1-100 人区分においては, 「農用地」 や「森林・荒地」といった粗放化に向かう土地利用変化が 多くみられるが，100-1000 人区分においては，「建物」メッ シュへの変化が最も多く，「農用地」や「森林・荒地」メッ シュへの変化割合は小さくなっている．1000-4000 人区分 および 4000 人以上の区分における土地利用変化の大部分 は「建物」メッシュへの変化となっている。「農用地」にお いても同様に, 1-100 人メッシュにおいては,「森林・荒地」 メッシュへの変化が多く粗放化されていること, 1000-4000
表-7 メッシュ人口変化率别 土地利用メッシュ数

\begin{tabular}{|c|c|c|c|c|c|}
\hline 1992 年度土地利用分類 & \multicolumn{5}{|c|}{ 建物 } \\
\hline 2009年度土地利用分類 & 建物（残存） & 田 & 農用地 & 森林・荒地 & 全メッシュ \\
\hline $\begin{array}{l}0 \text { (無住化) } \\
\end{array}$ & 2,151 & 155 & 521 & 697 & 4,006 \\
\hline $\begin{array}{l}0-25 \\
\end{array}$ & 4,951 & 695 & 1,207 & 1,276 & 8,562 \\
\hline $25-50$ & 21,699 & 3,539 & 3,736 & 4,300 & 34,660 \\
\hline $50-75$ & & 11,485 & 10,227 & 11,408 & 157,461 \\
\hline $75-100$ & 515,108 & 19,237 & 16,270 & 16,526 & $\begin{aligned} 583,725 \\
\end{aligned}$ \\
\hline $100-150$ & 499,840 & 15,594 & 13,744 & 11,129 & 555,425 \\
\hline $150-200$ & 45,880 & 2,654 & 2,594 & 2,046 & 54,908 \\
\hline $200^{-}$ & 25,402 & 1,870 & 2,155 & $\mid 1,726$ & 32,562 \\
\hline
\end{tabular}

\begin{tabular}{|c|c|c|c|c|c|}
\hline 1992年度士地利用分頪 & \multicolumn{5}{|c|}{ 田 } \\
\hline 2009年度土地利用分類 & 建物 & 田(䄀存) & 震用地 & 森林・荒地 & 全メッシュ \\
\hline 0 (無住化) & 436 & 12,747 & 2,975 & 4,755 & 21,943 \\
\hline $0-25$ & 1,622 & 39,021 & 6,091 & 10,017 & 58,042 \\
\hline $25-50$ & 8,813 & 165,311 & 15,857 & 29,293 & 223,351 \\
\hline $50-75$ & 40,332 & 469,294 & 27,065 & 52,095 & 601,136 \\
\hline $75-100$ & 122,171 & 674,791 & 34,977 & 47,303 & 901,605 \\
\hline$\frac{100-150}{100}$ & 144,016 & $\overline{524,304}$ & 28,106 & 32,196 & 750,299 \\
\hline $150-200$ & 22,084 & 109,331 & 6,777 & 8,295 & 150,818 \\
\hline $200-$ & 13,874 & 91,296 & 5,634 & 7,490 & 122,538 \\
\hline
\end{tabular}

\begin{tabular}{|c|c|c|c|c|c|c|}
\hline 1992年度土地利用分類 & \multicolumn{6}{|c|}{ 農用地 } \\
\hline 2009年度土地利用分類 & 建物（惐存） & 田 & 農用地（残存） & 森林・荒: & & 全メッシュ \\
\hline 0 (無住化) & 1,304 & 716 & 68,527 & & 3,501 & 87,802 \\
\hline $0-25$ & 2,783 & 2,250 & 95,134 & & 5,136 & $\overline{118,479}$ \\
\hline $25-50$ & 7,851 & 7,074 & 167,047 & & 0,753 & 217,685 \\
\hline $50-75$ & 26,319 & 15,784 & 269,517 & & 3,477 & 373,915 \\
\hline $75-100$ & 72,675 & 22,344 & 321,384 & & 2,836 & 483,018 \\
\hline$\frac{100-150}{100}$ & 88,014 & 18,675 & 259,164 & & 8,246 & 417,538 \\
\hline $150-200$ & 13,912 & 4,045 & 65,764 & & 9,297 & 96,202 \\
\hline $200-$ & 10,095 & 3,301 & 64,378 & & 9,479 & 90,993 \\
\hline
\end{tabular}

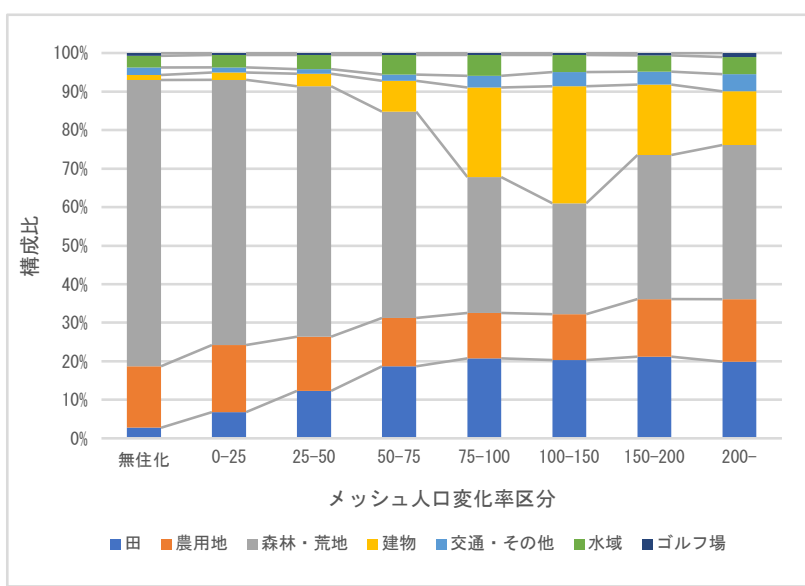

図-10２009年度メッシュ人口変化率別構成比

人区分及び 4000 人以上区分においては，「建物」メッシュ への変化となっている．このことから，一定の人口密度を 超えると「田」「農用地」は宅地化に向かうことがわかる.

\section{3-3 メッシュ人口変化率と土地利用変化との関係}

次に，1995 年および 2010 年のメッシュ人口の変化率に 着目した. メッシュ人口変化率(2010 年メッシュ人口/1995 年メッシュ人口)を，0 25\%, 25 50\%, 50 75\%, 75 100\%, 100 150\%，150 200\%，200\%以上，および0\%(無住化)の 8 区分に分類した上でデータを整理した．各区分におけるメ ッシュ数は表-6 の通りである.

1991 年度および 2009 年度土地類型別構成割合はそれ ぞれ図-9 および図-10 である. 1991 年度及び 2009 年度にお ける構成割合を比較すると,「建物」メッシュは人口変化率 
が 50\%以上の区分において大きく増加している. 特に人口 増地域においては，メッシュ構成比の増加が大きい(100150\%区分において約 19\%から約 30\%，150-200\%区分にお いて約 9\%から約 18\%，200\%以上区分において約 6\%から 約 $14 \%$ へと変化している). 人口増に伴う宅地化について観 察することができる.「田」メッシュは全区分において全区 分において約 2\% 5\%構成比が低下している．また，「農用 地」メッシュは, 人口変化率50\%未満の各区分においては 構成比が微増し，50\%以上の各区分においては構成比が微 減する.

各区分の残存率について整理したものが図-11 である. 「建物」メッシュは人口変化率が高くなるにつれて残存率
は増加し, 100-150\%区分において残存率が約 90\%と最も高 く，それ以上になると低下寸る。これは「森林・荒地」を 除いた全体平均と類似している。「田」メッシュは 50-75\% 区分において残存率が最も高くなり(約 78\%)，100-150\%区 分において極小值(約 70\%)をとる. またそれ以上の区分に おいては微増する。「農用地」メッシュは0-25\%区分におい て残存率が最も高く(約 80\%)，100-150\%区分において極小 值(約 62\%)をとり，それ以上の区分においては微増する.

以上のことから，人口減少地域においては，「建物」メッ シュは徐々に人口減少率が大きくなるにつれ変化する割合 が高くなること，「田」メッシュは一定の減少水準をこ えると変化割合が増加すること，「農用地」は人口減少が進

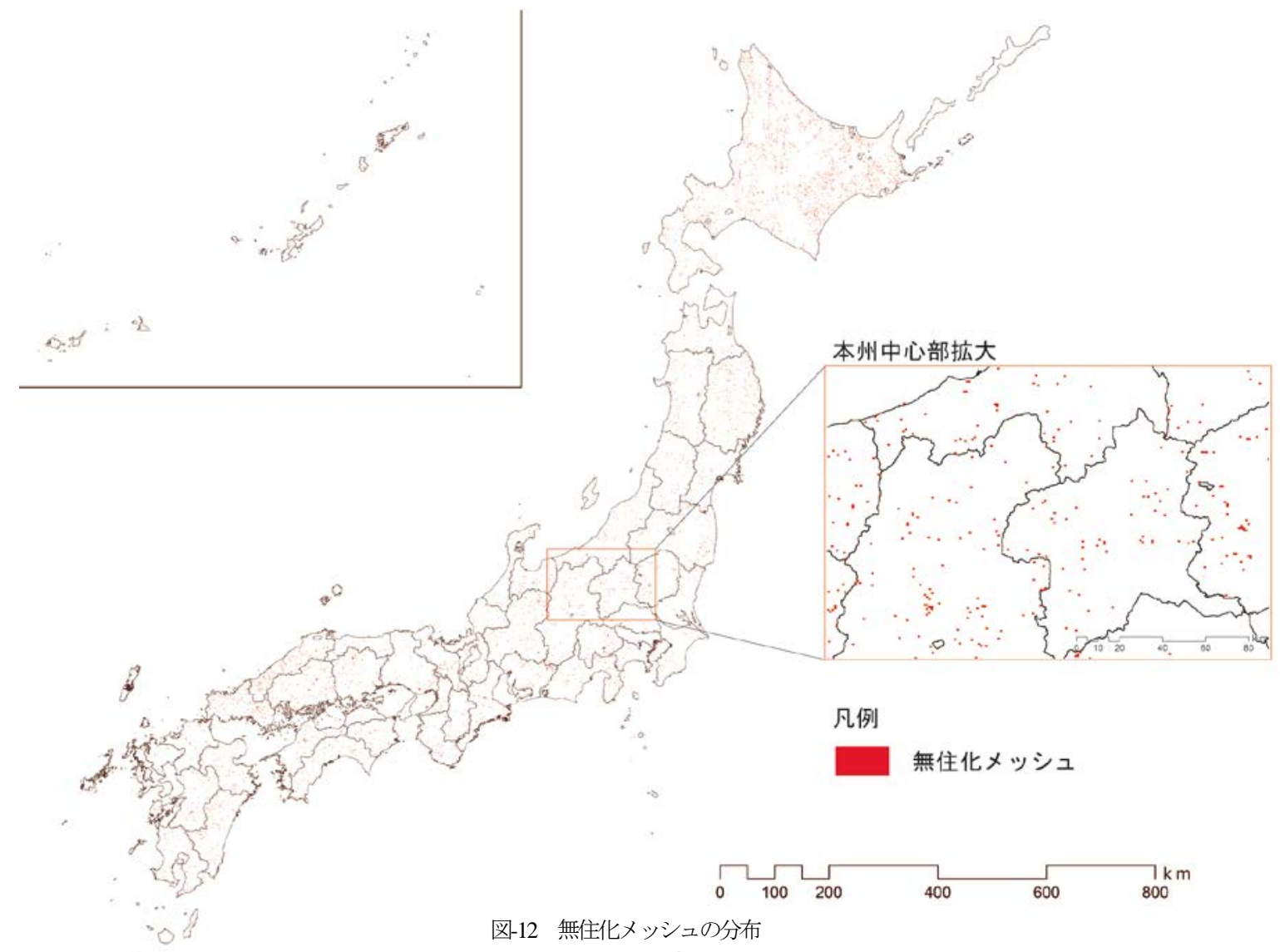

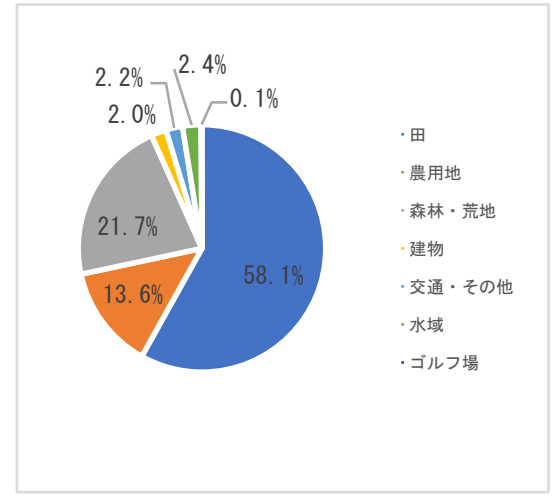

図-13 無住化メッシュにおける 1991 年度「田」 メッシュの2009年度土地利用類型

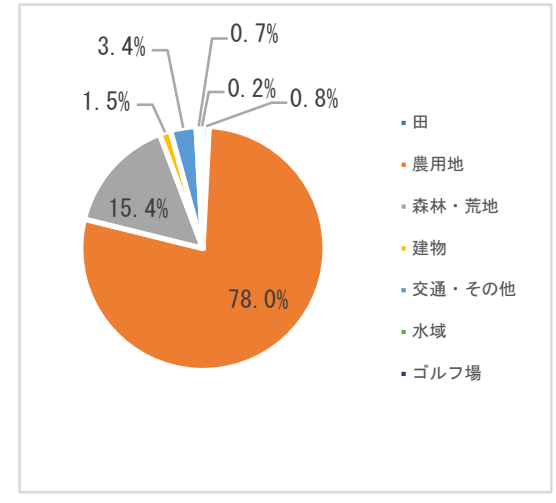

図-14 無住化メッシュにおける 1991 年度「農用 地」メッシュの 2009 年度土地利用類型

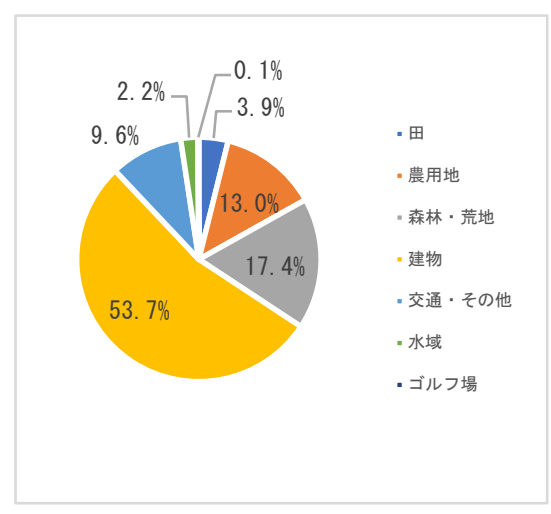

図-15＼cjkstart無住化メッシュにおける 1991 年度「建 物」メッシュの 2009 年度土地利用類型 
行した場合においても残存する割合が高く，人口減少が著 しく進行した場合においても土地利用が残存する場合が多 いことが示唆された

\section{4. 無住化地域における土地利用変化の傾向}

次に，無住化地域(1995 年においてメッシュ人口 1 人以 上であったが, 2010 年においてメッシュ人口 0 人であった 地域における土地利用変化についてその傾向を分析した. 対象メッシュ数は，表-7 にある通り約 57 万メッシュで女 る．無住化地域メッシュの分布図は，図-12 のようになっ た. 北海道や山間部ににおいて分布が多いものの，特徽的 な空間的偏在をみることはできない，

無住化地域における，土地利用変化について「田」「農 用地」「建物」メッシュにおける残存および構成割合を整理 したものが図-13,14,15 である.「田」メッシュは, 無住化地 域となっても 58.1\%が残存し，「農用地」や「森林・荒地 へと粗放化する割合は約 35\%となった。「農用地」メッシュ は，前述の通り残存率が高く，「森林・荒地」への粗放化す る割合は約 15\%にとどまる。「建物」メッシュにおいても半 数を超える 53.7\%が残存し，「農用地」や「森林・荒地」へ と粗放化した割合はそれぞれ 13.0\%および 17.4\%となって いる.

以上のことから，無住化によって土地利用が急速に粗放 化することはなく，「農用地」や「田」は引き続き生産的土 地利用が継続される割合も高い。また「建物」土地利用も 半数以上が残存することから，空き家が残されたままであ ることも推測される。

\section{5. 結論と今後の課題}

本研究では，国土数值情報土地利用細分メッシュデータ および国勢調査人口メッシュデータを結合した約 1350 万 余りのデータベースを構築し，それをもとに人口動態と土 地利用変化(残存)について整理・分析を行った. メッシュ人 口密度区分別およびメッシュ人口変化率区分別に整理する と，土地利用類型に応じて残存(変化)割合に特徵があるこ とを明らかにした．また，無住化地域においては，全国に ランダムに無住化地域が生じていることを指摘し，急速に 土地利用の粗放化が進むことはなく、「建物」メッシュにお いても半数以上が残存しており，空き家となっていること が推測されることを指摘した.

本研究では，土地利用および人口データの結合によるデ 一タベースで分析を行ったが，土地利用変化の要因につい ての分析については行っていない. 本研究において構築し たデータベースに地形的要因(標高・傾斜など)や交通・生活 利便性などの要件をさらに結合させることにより，土地利 用変化(残存)の傾向やその要因についてより詳細な分析が 可能になる. また，無住化地域における土地利用変化（特 に建物メッシュの残存傾向）について詳細に分析すること により，空き家の発生状況などを把握することが可能にな る. 更に，人口動態，土地利用双方において公開されてい
る他年次におけるデータを結合することにより，時系列ご との土地利用変化の傾向の違いについて分析することも可 能である．特に将来人口推計データを用いることで，今後 の土地利用 (国土利用) 変化について予測・分析寸るため の知見を得ることもできるであろう.

\section{補注}

（1） 1991 年度および 2009 年度における国土数值情報土地利用細分メッ シュにおいては，データ作成においては使用する衛星画像などが異 なるため全く同基淮で作成してはいないものの，参考文献5）および 6）をはじめ多くの研究おいて，作成方法の差異による誤差を無視し ていることから，本研究においてはメッシュデータの作成方法の違 いによる誤差については考慮していない，

（2）土地利用細分メッシュデータにおけけるメッシュコード10桁の上8桁 を抽出した上で，国勢調查人口メッシュデータにおけるメッシュコ ード 8 桁を GIS ソフトウエア上で一致させることにより結合を行っ た.

（3）「交通・その他」メッシュが 0.72 倍となり減少した要因は，1991年 度および2009年度における国土数值情報土地利用細分メッシュデー タの作成方法の違い（特に観覞衛星の違い）によるものと考えられ ろ.

\section{参考文献}

1）国土交通省(2014)，「国土のグランドデザイン 2050」

2）有賀敏典，松橋啓介(2012)，「地域内人口分布の偏在化・均一化シナリ 才構築手法の開発 -国勢調查3次メッシュデータを用いて-」, 都市計 画論文集，Vol.47 No.3，pp.745-750

3）中西賢也，小䛀知義，赤星健太郎，石井儀光，岸井隆幸(2011)，「メッ シュ単位の将来人口推計手法を用いた都市構造の可視化に関する研 究J，都市計画論文集，Vol.46 No.3，pp.445-450

4) 清水庸, 佐藤羊平, 山路永司(1999), 「統計的手法を用いた土地利用構 造の把握 - 日本全域を事例地域として-」, 農村計画学会誌, Vol.18 No.18, pp.331-336

5）菊池亮太, 室町泰德(2015), 腘土数值情報を用いた人口減少下の都市 における都市的および自然的土地利用の変化に関する分析」, 都市計 画論文集，Vol.50 No.3，pp.588-593

6)清水裕之(2015), 「標淮地域 3 次メッシュを用いた日本の国土の土地 利用変化と人口・世帯変化の観察と類型化 - 都市的土地利用に着目し て-」, 都市計画論文集，Vol.50 No.1，pp.107-117 